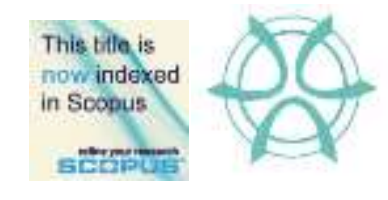

PLANNING MALAYSIA:

Journal of the Malaysian Institute of Planners

Volume XIII (2015), Page 65 - 84

\title{
ASSESSING THE URBAN AND RURAL STAGE BUS SERVICES DISPARITIES IN PENINSULA MALAYSIA
}

\author{
Zakiah Ponrahono' ${ }^{1}$, Syahriah Bachok ${ }^{2}$, Mariana Mohamed Osman ${ }^{3}$, Mansor \\ Ibrahim $^{4}$, Muhammad Faris Abdullah $^{5} \&$ Alias Abdullah ${ }^{6}$ \\ ${ }^{1}$ Department of Environmental Management, Faculty of Environmental Studies, \\ UNIVERSITI PUTRA MALAYSIA \\ 2,3,4,5\&6 Department of Urban and Regional Planning \\ INTERNATIONAL ISLAMIC UNIVERSITY MALAYSIA
}

\begin{abstract}
Disparities between services and goods provision have been the concerns of various regional development proponents. Among the gaps that needed to be addressed by regional policies and initiatives were accessibility and mobility levels between urbanites and the rural population. This study reports on the differences of the urban versus rural bus services. For this purpose, this study extends the exploration of approximately 48 routes within selected urban and regional settlements in Peninsula Malaysia, using a quantitative traffic engineering measure known as Level of Service standards or LOS. Three performance measures, namely fixed-route hour of service, fixed-route service frequency and passenger-load threshold were evaluated in determining the existence and extent of such disparities. The passengers' satisfaction and preference survey were conducted to complement some qualitative explanations left void by the LOS evaluation. Methods of on-board face to face intercept survey and adoption of Geographical Information System (GIS) /Global Positioning System (GPS) were deployed in the collection of primary data. More than 1600 survey forms were distributed, but after collection and data cleaning, only a total of 1130 were analysed. Findings of the study supported and confirmed the existence of such spatial imbalances of services provision. They also further accentuated that many developing nations' rural settlements were indeed stigmatised by a lower level of stage bus services (average at LOS D) compared to those enjoyed by the urbanites (average services at LOS C).
\end{abstract}

Keyword: transport planning; public transport; passenger's aspiration; onboard survey

${ }^{1}$ Tutor in Department of Environmental Management, Faculty of Environmental Studies, Universiti Putra Malaysia. Email: zakh@upm.edu.my 
Zakiah Ponrahono, Syahriah Bachok, Mariana Mohamed Osman, Mansor Ibrahim \& Muhammad Faris Abdullah \& Alias Abdullah Assessing The Urban And Rural Stage Bus Services Disparities In Peninsula Malaysia

\section{INTRODUCTION}

An issue greatly discussed by many regional stakeholders is the urban and rural divide of Malaysian mobility and accessibility levels (Nor \& Nor, 2006; Roslan, 2001; Siong, 2008; Thompson, 2004). This divide hindered systematic and comprehensive growth of rural areas especially in network infrastructure upgrading and accessibility improvement. One of the main contributors of the disparity is inefficient public transport system, whereby the lack of such system would limit the choices, circumstances and fortunes of the population to reach amenities and facilities as well as access the employment opportunities (Kamba, Rahmat, \& Ismail, 2007; Olsson, 2012; Pucher \& Renne, 2013).

In some parts of the world, public transportation, such as buses in urban areas, is an optional mode to overcome many traffic issues including to reduce congestion, to increase the coverage of distances and to improve the mobility levels (Abdullah, 2006; Ismail, Hafezi, Nor, \& Ambak, 2012; Jayaraman, Choong, Suan, \& Lin, 2011; Ponnaluri, 2011; Suwardo, Napiah, \& Kamaruddin, 2009; Yaakub \& Napiah, 2011a, 2011b). However, for some rural populations who are captive to buses, these are the only access modes to destinations near and far. Whilst many services are provided to varying degrees in Malaysia, less have been prioritised on ensuring the buses' integration, coordination and monitoring to reach an efficient level of sustainability (Hayashi, Doi, Yagishita, \& Kuwata, 2004).

This study engages with the current system of public bus services in four main conurbations and suburban areas of Malaysia. There existed some 62,672 buses registered in Malaysia (Ministry of Transport Malaysia, 2014), comprising five major systems namely stage bus (intra-city), minibus, express bus (interstate and intercity), school and factory workers' bus and feeder bus (Land Public Transport Commission (SPAD), 2012; Suruhanjaya Pengangkutan Awam Darat (SPAD), 2014a). Various subsystems such as fleets, management and operating, scheduling, routing, stops and termini, boarding and alighting facilities, fare and ticketing as well as passenger information support the vehicular services system (Land Public Transport Commission (SPAD), 2011; Suruhanjaya Pengangkutan Awam Darat (SPAD), 2014b). In Peninsula Malaysia, Acts of Parliament related to public buses including stage buses provide legislative backing of statutory roles and functions of the Suruhanjaya Pengangkutan Awam Darat (SPAD) or Land Public Transport Council (SPAD, 2014) to plan, develop, issue licenses, regulate and monitor, execute and upgrade these supply systems. Being one of the Prime Minister's departments, the Council is deemed to have credentials of ensuring that the delivery of bus services to be more effective, efficient and accountable (since it is partially subsidised by the government). 
PLANNING MALAYSIA

Journal of the Malaysia Institute of Planners (2015)

\section{RURAL VERSUS URBAN BUS SERVICES}

Issues of the urban-rural public bus in Malaysia received less than proportionate attention by the global literature (Abdullah, 2006; Ismail et al., 2012; Jayaraman et al., 2011; Ponnaluri, 2011; Suwardo et al., 2009; Yaakub \& Napiah, 2011a, 2011b). Whilst many research highlighted the issues pertinent to countries, regions, cities and ruralities facing imbalance physical and socio-economic growth, contemporary literature has focused more on cases of developed nations' urban-rural gaps (Hidding \& Teunissen, 2002; Odeck \& Alkadi, 2004; Odeck, 2006; Pucher \& Renne, 2013). Limited literature can be cited for an in-depth discussion on quality and performance (operation) of urban-rural public transportation especially buses in Malaysia (Jayaraman et al., 2011; Kamaruddin, Osman, Anizaliana, \& Pei, 2012; Napiah, Farid, \& Suwardo, 2010; Noor, Nasrudin, \& Foo, 2014; Sham, Samsudin, \& Rahman, 2013; Suwardo et al., 2009; Suwardo, Napiah, \& Kamaruddin, 2008a, 2008b). Most studies in public transportation were carried out in the specific areas of urban or rural localities distinctively, and these lack the comparative element in their discussion (Jayaraman et al., 2011; Kamaruddin et al., 2012; Napiah et al., 2010; Noor et al., 2014; Sham et al., 2013; Suwardo et al., 2009, 2008a, 2008b). Previous studies have purposively concentrated on ridership and improvement of bus services in a case study manner, providing scarce literature sources for regional disparities assessment. Hence, in-depth regional comparison and rigorous evaluation of rural-urban bus services divide is made difficult, if not impossible. This particular research fills in this literature gap.

Often, bus operations are varied by types and features, where distinctive characteristics are found between those of urban and rural, such as route coverage, fare and fleet systems (Odeck \& Alkadi, 2004). These systems and fleet characteristic variations have been attributable to the socio-economic, valuebelief-culture and geo-spatial differences of the localised needs. As nations grow, Asian urban centres are faced with mobility issues and automobile dependency. In rural areas, this effect is compounded by the limited alternatives (Bailey, 1986; Bell \& Cloke, 1991; Dandapat \& Maitra, 2015; Santoso, Yajima, Sakamoto, \& Kubota, 2012). Additionally, the existing public transport in both localities encountered problems of low and poor quality of service operation, infrastructure and facilities, the similar conditions faced by capital cities and rural settlements of Malaysia (Jayaraman et al., 2011).

Hook, (2006) suggested that costs and time are factors contributing towards the fewer trips made by the urban lower income groups in developing countries. In addressing this, it was argued that urban mass transit (public transport) provision would boost the efficiency of movement for lower income people. Examples of best practices can be found in Singapore's rail-based mass rapid transit (MRT). In many urban areas, due to barriers of high investments that 
rail is associated with, bus system such as Brazil's bus rapid transit (BRT) is considered a better and more functioning alternative to reduce automobile dependency, in pursuit of the preservation of the geo-cultural and sustenance of the regions (Currie \& Delbosc, 2014; Jaramillo, Lizárraga, \& Grindlay, 2012; Patrick \& Roseland, 2005). However, this situation may not be a true reflection of the urban-rural public bus ridership reality in Malaysia. Whilst programmes of bus services transformation may be adopted for urban systems, different treatments may be necessary in rural areas which have a lower density and diverse population activities within sparse geographical areas.

The Level of Service (LOS) and passengers' satisfaction are two viable measurement tools in assessing bus services performance (Chen, Yu, Zhang, \& Guo, 2009). Target performance improvements are increased overall quality, reliability, efficiency and effectiveness of the system. Not only service quality is measured from the aspects of operation and management, the performance can also be evaluated against the perception and expectation of the passengers, who are the end users. Evaluating passengers' satisfaction level towards buses would help identify the service quality and areas of necessary improvements (Zakaria, Hussin, Batau, \& Zakaria, 2010). Even though there exists no specific standard measurement tool or parameter that can be applied universally, the attributes in LOS and passengers' satisfaction study are considered by scholars as sufficient for service quality assessment (Samir, 2001; State of Florida Department of Transport, 2013). In short, LOS measures the service quality from the perspectives of existing passengers on the bus services, while providing insight to the aspiration of what matters the most for the current and future the users of buses.

The bus services and system provision may differ between urban and rural areas. Geo-spatial factors such as population density, weather and environmental conditions, economic and values/beliefs/cultural may influence the quality provided (Odeck \& Alkadi, 2004). Similarly, route alignment and coverage, fare rates and fleet size provided may also depend on the local needs (Rohani, Wijeyesekera, \& Karim, 2013; Sham et al., 2013; Sham, Soltani, Sham, \& Mohamed, 2012). More often than not, urban and rural transportation face issues of service operation, infrastructure and facilities provision, scenarios often associated with those of Malaysian case study (Ariffin \& Zahari, 2013). For example, rural European public buses compared to those of urban, are functional and practical as modes to reduce the private vehicle dependency for sustainability and to preserve the geo-culture (Patrick \& Roseland, 2005). In rural Malaysia, bus services are provided as a social obligation rather than driven by the market or by income levels and trip patterns of the users (Ismail et al., 2012; Noor et al., 2014). Hence, addressing rural bus issues may require different treatment due to 
the population size, density and sparse locations of the trip attractions (Ariffin \& Zahari, 2013).

Santoso, Yajima, Sakamoto, \& Kubota, (2012) highlight that since rural areas rarely face traffic issues like congestion and insufficient parking spaces, dependency on private vehicles is inevitable. Any attempt to provide sustainable bus services or improve the existing system would be a challenge. Hence, an expected scenario most likely experienced by rural Malaysians is one where low ridership on older fleets, passengers riding the scanty services with minimum amount of complaints and inter-district or even door to door service to the population. This study aims at confirming such scenario, by identifying differences and similarities between urban and rural public buses services in Malaysia, a gap clearly mooted by the literature. It is also the aim of the study to analyse the quality of services in the selected urban and rural settlements in Peninsula Malaysia for the purpose of generalizing the quantum and magnitude of public bus system issues.

\section{RESEARCH AIM AND OBJECTIVES}

Having identified research gaps and problem statements, the following objectives are formulated:

1. To determine the existence and magnitude of LOS difference between services of selected urban and rural centres of Peninsula Malaysia

2. To analyze the bus passengers' preferences and aspirations

\section{RESEARCH METHODOLOGY}

\section{Sampling Frame}

Using purposive sampling technique, four states with generic and homogeneous public buses have been selected to represent the variation of services performance (Royce A. Singleton \& Straits, 2010; Creswell, 2009; Sarantakos, 2005). First, Pahang, Perak, Pulau Pinang and Johor were selected because the bus services were provided in both the urban centres and settlements with rural characteristics. Second, these urban centres are Georgetown, Kuantan, Johor Bahru and Ipoh, selected based on the regional conurbation definitions and zones by National Physical Plan 2 (Federal Department of Town and Country Planning Ministry of Housing and Local Government of Malaysia, 2010). Third, settlements with rural characteristics were purposively identified to be on certain radius limit of geographical proximity or a satellite town or hinterland servicing the major conurbations. Finally, these rural case studies has a single bus service provider using conventional system, lower and older conditions of fleets and not supported 
by other public transport systems with the exception of informal paratransit such as informal car rental (kereta sapu). The four rural settlements are:

i. Pekan, Batu Pahat and Kerian (Pekan District Office, Batu Pahat District Office and Kerian District Office), settlements that centered on small or intermediate towns.

ii. Batu Pahat as included in the zone of Muar-Batu Pahat-Kluang District Growth Conurbation in National Physical Plan 2 (Federal Department of Town and Country Planning Ministry of Housing and Local Government of Malaysia, 2010).

iii. Seberang Prai bus route coverage includes suburb and small villages in Penang.

The present population and recorded bus users as supplied by the operators of the selected settlements against the number of operators and routes registered are detailed in the Table below:

Table 1: Population, Number of Bus Operators and Bus Routes of the Selected Case Studies

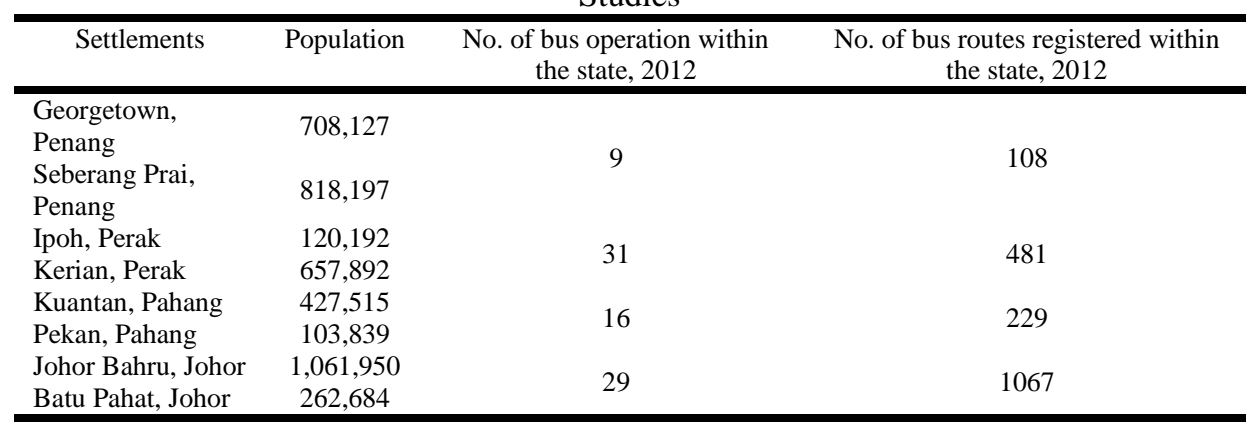

\section{Sampling Unit}

The unit of analysis for LOS evaluation was the bus services performance as quantitatively defined by the relevant authorities, whereas the unit of analysis for satisfaction survey was the bus rider selected as the respondent when encountered by the enumerators. As such, convenience sampling (Cinquina, 2006; Jayaraman et al., 2011) was deemed most suited for this kind of study due to the nature of moving vehicles within the specific distance, routes and speed driven by the drivers. Face to face intercept survey ensures the comfort of passengers without compromising the limitation experienced by the enumerators to ask questions, mobility and ease with which the enumerators to move on board the buses and approach the prospective riders. Thus, it is inevitable that sampling strategy may have a greater tendency to select 
passengers seated or standing near, next to, behind, in front or beside the enumerators when and if a crash load of passengers' boarding reached maximum level or beyond the tolerable threshold. Employing the 95 percent confidence level and confidence interval, the following algorithm by Yamane, (1967) is adopted to ascertain the minimum sample size for each of the case studies.

Given the confidence level $=95 \%$, and $\mathrm{P}=0.05$

$$
\begin{aligned}
& \boldsymbol{n}=\frac{\boldsymbol{N}}{1+\boldsymbol{N}(e)^{2}} \quad \frac{2,739,544}{1+2,739,544(0.05)^{2}}=399.9 \text { people } \\
& \boldsymbol{n}=\underline{\mathbf{4 0 0}}
\end{aligned}
$$

For each case study state (Perak, Pahang, Pulau Pinang and Johor) a minimum of 300 samples were targeted to be collected, thus 1200 samples for the overall study. In this study, to achieve the targeted samples, an optimal 140 survey forms were distributed to passengers of the bus as soon as the bus move from the terminal. Optimally, from the nine (9) terminals, it was aimed that some 1260 samples to be collected. However, enumerators were working on the basis of approved and permitted survey duration and survey routes allowable by the operators. As such, after data cleaning, only 1130 survey forms were analysed for generalisation purposes. Some terminals have higher and more than proportionate samples due to a higher number of riders and greater concentration of route coverage. Table 2 details out the distribution of respondents by urban-rural centres.

Table 2: Distribution of Sampling Unit for On-Board Survey

\begin{tabular}{llccc}
\hline Centre & Terminal & Population & $\begin{array}{c}\text { No of } \\
\text { Respondent }\end{array}$ & $\begin{array}{c}\text { Percentage (\%) } \\
\text { over population }\end{array}$ \\
\hline Kerian, Perak & Parit Buntar & 120,192 & 100 & 0.08 \\
Ipoh, Perak & Medan Kidd & 46,629 & 105 & 0.23 \\
Seberang Prai, Penang & Penang Sentral & 545,688 & 101 & 0.02 \\
Georgetown, Penang & Jetty Terminal & 518,478 & 100 & 0.02 \\
Kuantan, Pahang & Hentian Bandar & 347,204 & 130 & 0.04 \\
Pekan, Pahang & Pekan & 103,839 & 108 & 0.10 \\
Johor Bahru, Johor & Larkin Terminal & 424,648 & 60 & 0.06 \\
Batu Pahat, Johor & Johor Bahru Sentral & 209,461 & 200 & 0.11 \\
\hline TOTAL & Batu Pahat & $\mathbf{2 , 3 1 6 , 1 3 9}$ & $\mathbf{1 1 3 0}$ & $\mathbf{0 . 0 5}$ \\
\hline
\end{tabular}


Zakiah Ponrahono, Syahriah Bachok, Mariana Mohamed Osman, Mansor Ibrahim \& Muhammad Faris Abdullah \& Alias Abdullah Assessing The Urban And Rural Stage Bus Services Disparities In Peninsula Malaysia

\section{On-board public bus survey}

Adopting face to face intercept survey has the greater advantage over other methods in capturing passengers' demographic and travel characteristics. This method provided greater reliability, validity, credibility and precision or accuracy of data since passengers can easily recall, reflect and approximate their journey experiences with the very trip they were making when they were interviewed on board (Yaakub \& Napiah, 2011a).

\section{Procedure}

Surveys were conducted were carried out on several bus trips during both weekdays and weekend. The on-board passengers' responses were capture according to the schedule below:

Error! Reference source not found.*Intercept face to face conducted during off peak Figure 1: Onboard Survey Period Conducted

\section{Questionnaire}

The variables to be collected for purposes of bus performance evaluation and improvements aspired by passengers have been translated into questions in the survey forms. This questionnaire was divided into two sections namely sections A and B. Section A consisted of the socio-demographic and trip characteristics. Meanwhile, Section B evaluated the satisfaction level with the current services as well as respondents' preferences and aspirations. The quality of bus services in the selected case studies were assessed against three performance measuring standards or Level of Service LOS (Tables 3 through to 8):

First, the fixed-hour service LOS definitions were provided Transportation Research Board, (2003). This measured the bus services availability and the capacity of the fleet. 
Table 3: Fixed-route Hour of Service LOS

\begin{tabular}{ccl}
\hline LOS & Hours of service & Remarks \\
\hline A & $19-24$ & Night 'owl' service provided \\
B & $17-18$ & Late evening service provided \\
C & $14-16$ & Early evening service provided \\
D & $12-13$ & Daytime service provided \\
E & $4-11$ & Peak hour service only or limited midday service \\
F & $0-3$ & Very limited or no service \\
\hline
\end{tabular}

Second, the measurement was made on the average frequency of bus within the waiting time, which is also known as the fixed-route service frequency LOS. Meanwhile, headway is a derivation of frequency of services, whereby in a service of two buses per hour i.e. the frequency of two per hour, the headways between two buses were thirty minutes.

Table 4: Fixed-route Service Frequency LOS

\begin{tabular}{cccl}
\hline LOS & Average Headway $(\mathrm{min})$ & Vehicle per hour & Remarks \\
\hline A & $<10$ & $>6$ & Passengers do not need schedules \\
B & $10-14$ & $5-6$ & Frequent service, passengers consult schedules \\
C & $15-20$ & $3-4$ & Maximum desirable time to wait if bus/train \\
missed \\
E & $21-30$ & 2 & Service unattractive to choice riders \\
F & $31-60$ & 1 & Service available during the hour \\
\hline
\end{tabular}

Source: Noorfakhriah and Madzlan, 2001, p.5

Another measurement is the degree with which maximum allowable seating and standing capacity of a vehicle fleet is reached. This is known as passenger loading LOS.

Table 5: Passengers Loading LOS Thresholds

\begin{tabular}{ccl}
\hline LOS & Passengers /Seat & Remarks \\
\hline A & $0.00-0.50$ & No passenger needs to sit next to another \\
B & $0.51-0.75$ & Passengers can choose where to sit \\
C & $0.76-1.00$ & All passengers can sit \\
D & $1.01-1.25^{*}$ & Comfortable standee load for urban transit \\
E & $1.26-1.50^{*}$ & Maximum schedule load for urban transit \\
F & $>1.50^{*}$ & Crush load \\
\hline
\end{tabular}

*approximate values for comparison

Source: Transport Research Board of National Academics TCRP Report 100 (TCQSM 2003) as cited in M. Napiah et al., (2010)

Bus services performance is also possibly measured using the speed with which the buses travel. Bus speed LOS is a good measurement of how the buses deal with the traffic conditions. 
Zakiah Ponrahono, Syahriah Bachok, Mariana Mohamed Osman, Mansor Ibrahim \& Muhammad Faris Abdullah \& Alias Abdullah Assessing The Urban And Rural Stage Bus Services Disparities In Peninsula Malaysia

Table 6: Bus Speed LOS

\begin{tabular}{|c|c|c|c|}
\hline LOS & $\begin{array}{l}\text { Speed } \\
(\mathrm{km} / \mathrm{h})\end{array}$ & $\begin{array}{l}\text { Adapted from Ministry } \\
\text { Development India, }\end{array}$ & $\begin{array}{l}\text { Adapted from Cortés, Gibson, } \\
\text { Gschwender, Munizaga, \& } \\
\text { Zúñiga, (2011) }\end{array}$ \\
\hline A & $>30$ & $\begin{array}{l}\text { Primarily free flow movement at average } \\
\text { travel speeds usually about } 70 \% \text { of the free } \\
\text { flow speed for the key corridors. }\end{array}$ & Excellent \\
\hline B & $<25$ to $\leq 30$ & \multirow{2}{*}{$\begin{array}{l}\text { Small increase in traffic causing substantial } \\
\text { increase in approach delay and hence, } \\
\text { decrease in arterial speed. }\end{array}$} & Good \\
\hline $\mathrm{C}$ & $<21$ to $\leq 25$ & & Fair \\
\hline $\mathrm{D}$ & $<19$ to $\leq 21$ & $\begin{array}{l}\text { Significant approach delays and average } \\
\text { travel speed of } 1 / 3 \text { the free flow speed or } \\
\text { lower. Such conditioans causing } \\
\text { combination of one or more reasons such as } \\
\text { high signal density, extensive queing at } \\
\text { critical intersections and inappropriate signal } \\
\text { timing. }\end{array}$ & Barely acceptable \\
\hline $\mathrm{E}$ & $<15$ to $\leq 19$ & \multirow{2}{*}{$\begin{array}{l}\text { Key corridors at extremely low speeds below } \\
1 / 3 \text { to } 1 / 4 \text { of the free flow speed. Intersection } \\
\text { congestion is likely at critical signalized } \\
\text { locations, with high approach delays }\end{array}$} & $\mathrm{Bad}$ \\
\hline $\mathrm{F}$ & $\leq 15$ & & Very Bad \\
\hline
\end{tabular}

Table 7 provides the threshold levels for each of the four measurements. Level D was determined as the minimum tolerable threshold for public transportation (State of Florida Department of Transport, 2013), whereas traffic engineers are familiar with Level C for private transportation systems (Clifton \& Blohm, 2007; The City of San José, 2009).

Table 7: Acceptable Level of Service (LOS) Range

\begin{tabular}{l|l}
\hline Determinant & Minimum Range of Acceptable Level of Service (LOS) \\
\hline Fixed-route hour service & D : Daytime service provided \\
Fixed-route Service Frequency & D : Service unattractive to choice riders \\
Passengers Thresholds & D : Comfortable standee load for urban transit \\
Stage Bus Speed & D : Barely acceptable \\
\hline
\end{tabular}

*All LOS below than acceptable range as above were determined as low or poor level of service.

Other methods of scoring may also be applicable to determine the LOS of public buses in the case studies (Orth, Dorbritz, \& Weidmann, 2011; Samir, 2001). Table 8 details out the scoring range of LOS performance measure to adapted by this study. It can be seen that the higher the LOS e.g. A or B, the more scores the performance would be associated with. 
PLANNING MALAYSIA

Journal of the Malaysia Institute of Planners (2015)

Table 8: Score Range of Level of Service (LOS) Performance Measure Adaptation

\begin{tabular}{cccc}
\hline $\begin{array}{c}\text { LOS } \\
\text { Range }\end{array}$ & $\begin{array}{c}\text { Score Range developed by } \\
\text { Samir, (2001) }\end{array}$ & $\begin{array}{c}\text { Score Range developed by } \\
\text { Orth et al., (2011) }\end{array}$ & $\begin{array}{c}\text { Score Range adapted for } \\
\text { this study }\end{array}$ \\
\hline A & 5 & 6 & 6 \\
B & 4 & 5 & 5 \\
C & 3 & 4 & 4 \\
D & 2 & 3 & 3 \\
E & 1 & 2 & 2 \\
F & 0 & 1 & 1 \\
\hline
\end{tabular}

Source: (Orth et al., 2011; Samir, 2001)

\section{FINDINGS AND DISCUSSION}

Several findings were derived from the secondary and field surveys. First, the majority of the case studies have the bus services operated by a main provider or a single company operator, with the exception of Johor where multiple operators were servicing both the conurbations and rural settlements. Table 9 outlines the various operators by number of routes against geographical locations. The surveys were conducted on a total of 48 routes, 30 in urban areas and the remaining 18 in rural settlements. Disparities are glaring whereby most urban areas with the exception of Pulau Pinang have higher number of routes compared to those of rural.

Table 9: Bus Service Provider and Routes Coverage (Observed and Surveyed)

\begin{tabular}{|c|c|c|c|c|}
\hline \multirow{2}{*}{ State } & \multicolumn{2}{|l|}{ Selected Case Studies } & \multicolumn{2}{|c|}{ Number of Routes } \\
\hline & Urban Settlement & Rural Settlement & Urban & Rural \\
\hline Perak & $\begin{array}{l}\text { - Main provider of bus } \\
\text { consortium; Perak Transit Bhd } \\
\text { - Multiple private operators }\end{array}$ & $\begin{array}{l}\text { Single Private Operator; } \\
\text { The Red Omnibus Sdn. } \\
\text { Bhd }\end{array}$ & 6 & 3 \\
\hline Penang & Main provider; Operator A & & 6 & 11 \\
\hline Pahang & Main provider;RapidKuantan & $\begin{array}{l}\text { Single Private Operator; } \\
\text { Rahmat Alam Sdn. Bhd }\end{array}$ & 12 & 2 \\
\hline Johor & $\begin{array}{l}\text { Multiple Private Operators; } \\
\text { Syarikat Maju Sdn. Bhd \& } \\
\text { CausewayLink Sdn. Bhd }\end{array}$ & $\begin{array}{l}\text { Two Private Operator; } \\
\text { CausewayLink Sdn. Bhd } \\
\text { \& Johore Motor Sdn. Bhd }\end{array}$ & 6 & 2 \\
\hline TOTAL & & & 30 & 18 \\
\hline
\end{tabular}

Second, the study found that LOS were ascertained to be varied even among the four performance measurements namely fixed route hour, frequency, passenger load and speed. Disparities between urban and rural were clear as only one of five measurements in rural areas achieved the minimum tolerable level. Only bus speed in rural areas (LOS C) surpassed LOS D, the threshold. Other achievements were LOS D, E, E and F, respectively. Passenger loads during the weekend were in the worst condition or LOS F. This reflected the lowest ridership of rural areas, especially during Sundays. 
In contrast, two of the measurements applied on urban buses achieved better than the threshold at LOS C (for fixed route hour service and speed). The services of urban buses performed better than those or rural in passenger loads during the weekend. Performances in frequency and passenger loads during weekdays were comparable to those of rural areas.

Next, scoring measurement highlighted that there was a comparable scoring between services provided both in urban and rural areas. Nevertheless, scoring of rural areas (average 2.4 point) was lower than that of urban (2.8 points), indicating a mild disparity between urban and rural services.

Table 10: Summary of Mean Scores for LOS of Selected Urban-Rural Bus Services in Peninsula Malaysia

\begin{tabular}{|c|c|c|c|c|c|c|c|c|c|c|c|c|c|c|c|c|c|c|}
\hline \multirow{3}{*}{$\begin{array}{l}\text { Performance } \\
\text { Measure }\end{array}$} & \multicolumn{9}{|c|}{ Urban } & \multicolumn{9}{|c|}{ Rural } \\
\hline & \multicolumn{6}{|c|}{ Frequency of LOS (W) } & \multirow{2}{*}{\begin{tabular}{|l} 
LOS \\
Score \\
$(\Sigma)$ \\
\end{tabular}} & \multirow{2}{*}{$\begin{array}{l}\text { Mean } \\
\text { LOS } \\
(\mathrm{X})\end{array}$} & \multirow[b]{2}{*}{ LOS } & \multicolumn{6}{|c|}{ Frequency of LOS (W) } & \multirow{2}{*}{$\begin{array}{l}\text { LOS } \\
\text { Score } \\
(\Sigma)\end{array}$} & \multirow{2}{*}{$\begin{array}{l}\text { Mean } \\
\text { LOS } \\
(\mathrm{X})\end{array}$} & \multirow[b]{2}{*}{ LOS } \\
\hline & A & B & C & D & E & F & & & & A & B & $\mathrm{C}$ & D & E & $\mathrm{F}$ & & & \\
\hline $\begin{array}{l}\text { Fixed-route } \\
\text { hour service }\end{array}$ & 0 & 16 & 8 & 5 & 1 & 0 & 129 & 4.30 & C & 0 & 0 & 11 & 4 & 2 & 0 & 60 & 3.53 & $\mathrm{D}$ \\
\hline Frequency & 0 & 2 & 2 & 14 & 12 & 0 & 84 & 2.80 & $\mathrm{E}$ & 0 & 0 & 2 & 1 & 11 & 4 & 37 & 2.06 & $\mathrm{E}$ \\
\hline $\begin{array}{l}\text { Passengers } \\
\text { Load } \\
\text { (Weekdays) }\end{array}$ & 5 & 1 & 4 & 2 & 1 & 14 & 73 & 2.70 & $\mathrm{E}$ & 3 & 2 & 0 & 3 & 0 & $\begin{array}{l}1 \\
0\end{array}$ & 47 & 2.61 & $\mathrm{E}$ \\
\hline $\begin{array}{l}\text { Passengers } \\
\text { Load } \\
\text { (Weekend) }\end{array}$ & 1 & 2 & 0 & 2 & 0 & 6 & 28 & 2.55 & $\mathrm{E}$ & 0 & 0 & 0 & 1 & 1 & 3 & 8 & 1.60 & $\mathrm{~F}$ \\
\hline Bus Speed & 9 & 7 & 4 & 0 & 3 & 4 & 115 & 4.26 & $\mathrm{C}$ & 8 & 5 & 2 & 1 & 2 & 0 & 88 & 4.89 & $\mathrm{C}$ \\
\hline
\end{tabular}

* Score Range: $\mathrm{A}=6, \mathrm{~B}=5, \mathrm{C}=4, \mathrm{D}=3, \mathrm{E}=2$, and $\mathrm{F}=1$.

Where:

1. $\mathbf{W}=$ frequency of LOS obtained

2. $\mathbf{T}=$ score range $(\mathrm{A}=6, \mathrm{~B}=5, \mathrm{C}=4, \mathrm{D}=3, \mathrm{E}=2$, and $\mathrm{F}=1$. $)$

3. $\mathbf{N}=$ total case studies (routes surveyed)

4. $\mathbf{X}=$ mean LOS

5. LOS Score: $\boldsymbol{\Sigma}=\mathbf{W} \times \mathbf{T}$

6. Mean: $(\mathbf{X})=\Sigma / \mathbf{N}$

The reflection of disparities between urban and rural bus services would inevitably influence the determination of route coverage, fare system and fleets provided by the operators (Rohani et al., 2013; Sham et al., 2013, 2012). As such, treatments of varying degrees should be initiated on performance of fixed routes hour services and passenger loads during weekends to bridge the services gaps experienced by the rural bus operations. More suitable operation hours and promotion of choice trips with higher bus frequency during weekends must be undertaken by operators of rural bus services.

From the average and disaggregated scoring measurement, it is confirmed that the overall bus services were still poor or low, be it in urban areas or rurality. 
The crush load situation (Level F, more than 1.5 capacity factor) has created uncomfortable and inconvenience riding experience for the passengers. It becomes worse during public holidays or special events/occasion when passenger volume was overloaded and severe traffic congestion occurred. Other contributing factors may include lower frequency of services on weekends as well as lower quality fleets were deployed in the rural areas.

It can also be discussed that in rural areas particularly, travel time became longer and the last bus trip was sometimes cancelled by the operators/drivers by choice or unintentionally because they already reached the maximum operation hours. In rural areas, more often than not, buses frequency was less desirable than those of urban. Furthermore, spiraling the effects of lower load, rural buses have less revenues and profit, thereby compromising the fleet quality and comfort/convenient (Transportation Research Board, 2013). The domino effects are less attractive services resulting in lower ridership levels and lower reliability of the services for the rural population. In the worst case scenario, this will result in the collapse and closure of certain routes, as have been deliberated by more than one of the operators.

Further discussion of the above three major findings is regarding the gaps of services between two geographical settings based on operating system (Ariffin \& Zahari, 2013; Odeck \& Alkadi, 2004; Patrick \& Roseland, 2005; Rohani et al., 2013; Sham et al., 2013, 2012). In many rural areas and one or two urban bus services, delivery was by a single operator or a monopoly. This is a major factor that influences the lower and poorer quality of the service, leading towards less competitive or an imperfect market. In a market inequilibrium, passengers received less choices, limited exposure to higher quality services and normally being complacent or more receptive of the lower than appropriate levels of buses services quality. As such, morale and motivation to complaint about poor bus services were lower as propagated by many previous researchers (Aziz \& Amin, 2012; Bachok, 2007; Ismail et al., 2012; Jayaraman et al., 2011; Kamba et al., 2007).

On the outset, the overall bus services (LOS E) in Malaysia was not comparable even to the minimum levels of those tolerable by the more developed countries i.e. LOS D (State of Florida Department of Transport, 2013). With greater disparities between urban and rural areas, it can be expected that the quality of the current or existing bus services left much to be desired. These facts could not be captured by the LOS performance evaluation. As such, passengers' satisfaction and aspiration surveys were needed to fill in the qualitative explanation that left void by the LOS evaluation. 
Zakiah Ponrahono, Syahriah Bachok, Mariana Mohamed Osman, Mansor Ibrahim \& Muhammad Faris Abdullah \& Alias Abdullah Assessing The Urban And Rural Stage Bus Services Disparities In Peninsula Malaysia

Table 10: Final Mean Score and LOS categorization for LOS of Selected Urban-Rural Bus Services in Peninsula Malaysia

\begin{tabular}{|c|c|c|c|c|c|c|c|c|c|c|}
\hline \multirow[b]{2}{*}{$\begin{array}{l}\text { Performance } \\
\text { Measure }\end{array}$} & \multicolumn{5}{|c|}{ Urban } & \multicolumn{5}{|c|}{ Rural } \\
\hline & $\begin{array}{c}\text { Mean } \\
(\mathrm{X})\end{array}$ & LOS & $\begin{array}{c}\text { LOS } \\
\text { Score } \\
(\Sigma)\end{array}$ & $\begin{array}{c}\text { Mean } \\
\text { LOS } \\
(\mathrm{X})\end{array}$ & $\begin{array}{c}\text { Overall } \\
\text { LOS }\end{array}$ & $\begin{array}{l}\text { Mean } \\
(\mathrm{X})\end{array}$ & LOS & $\begin{array}{c}\text { LOS } \\
\text { Score } \\
(\Sigma)\end{array}$ & $\begin{array}{c}\text { Mean } \\
\text { Score } \\
\text { (X) }\end{array}$ & $\begin{array}{c}\text { Overall } \\
\text { LOS }\end{array}$ \\
\hline $\begin{array}{l}\text { Fixed-route hour } \\
\text { service }\end{array}$ & 4.30 & $\mathrm{C}$ & 4 & \multirow{6}{*}{2.8} & \multirow{6}{*}{$\mathrm{E}$} & 3.53 & D & 3 & \multirow{6}{*}{2.4} & \multirow{6}{*}{$\mathrm{E}$} \\
\hline Frequency & 2.80 & E & 2 & & & 2.06 & E & 2 & & \\
\hline $\begin{array}{l}\text { Passengers Load } \\
\text { (Weekdays) }\end{array}$ & 2.70 & E & 2 & & & 2.61 & E & 2 & & \\
\hline $\begin{array}{l}\text { Passengers Load } \\
\text { (Weekend) }\end{array}$ & 2.55 & E & 2 & & & 1.60 & $\mathrm{~F}$ & 1 & & \\
\hline Stage Bus Speed & 4.26 & $\mathrm{C}$ & 4 & & & 4.89 & $\mathrm{C}$ & 4 & & \\
\hline Total Score & & & 14 & & & \multicolumn{2}{|c|}{ Total Score } & 12 & & \\
\hline
\end{tabular}

* Score Range: $\mathrm{A}=6, \mathrm{~B}=5, \mathrm{C}=4, \mathrm{D}=3, \mathrm{E}=2$, and $\mathrm{F}=1$

Where:

1. $\mathbf{W}=$ frequency of $\mathrm{LOS}$ obtained

2. $\mathbf{T}=$ score range $(\mathrm{A}=6, \mathrm{~B}=5, \mathrm{C}=4, \mathrm{D}=3, \mathrm{E}=2$, and $\mathrm{F}=1$. $)$

3. $\mathbf{N}=$ total case studies (routes surveyed)

4. $\mathbf{X}=$ mean LOS

5. LOS Score: $\boldsymbol{\Sigma}=\mathbf{W} \mathbf{x} \mathbf{T}$

6. Mean: $(\mathbf{X})=\Sigma / \mathbf{N}$

Table 11 depicts the satisfactory level disparities between urban and rural passengers. Passengers in the surveys have been asked to recall trips made using buses either previously or the ones that they were currently experiencing. From the Table, one of the many conclusions is that disparities between urban and rural were most dramatic in the bus conditions and punctuality. In rural areas, passengers were in the opine that bus conditions were poor (67.4\%) compared to $32.6 \%$ rating by the urban riders. Rural population were also not choosing to ride the bus due to factor of punctuality (only $24.7 \%$ ) compared to those in urban areas $(75.3 \%)$.

Secondly, from Table 11, satisfaction levels were less varied but still distinguishable between urban and rural passengers. Whilst more urbanites were more dissatisfied with the services $(51 \%)$ than rural riders $(49 \%)$, the former believed that safety $(60.9 \%)$ was a positive factor to attract urban passengers towards buses compared to rural passengers $(39.1 \%)$.

Thirdly, another gap between urban and rural users of buses can be found in their respective perception of reliability of the bus services. Urban users who could be more exposed to higher quality services elsewhere or prior to being surveyed, were less receptive of the reliability (32.7\%) of the current bus system compared to rural people (67.3\%). 
PLANNING MALAYSIA

Journal of the Malaysia Institute of Planners (2015)

Finally, rural people surveyed were also more complacent about the bus conditions, despite the lower quality of, comfort levels and convenience offered by the fleet by perceiving the conditions to be between poor and good (73.9\%). Urban riders were very critical of this view, by recording only $26.1 \%$ response for this category.

Table 11: Bus Services Satisfactory Level between Urban and Rural Passengers

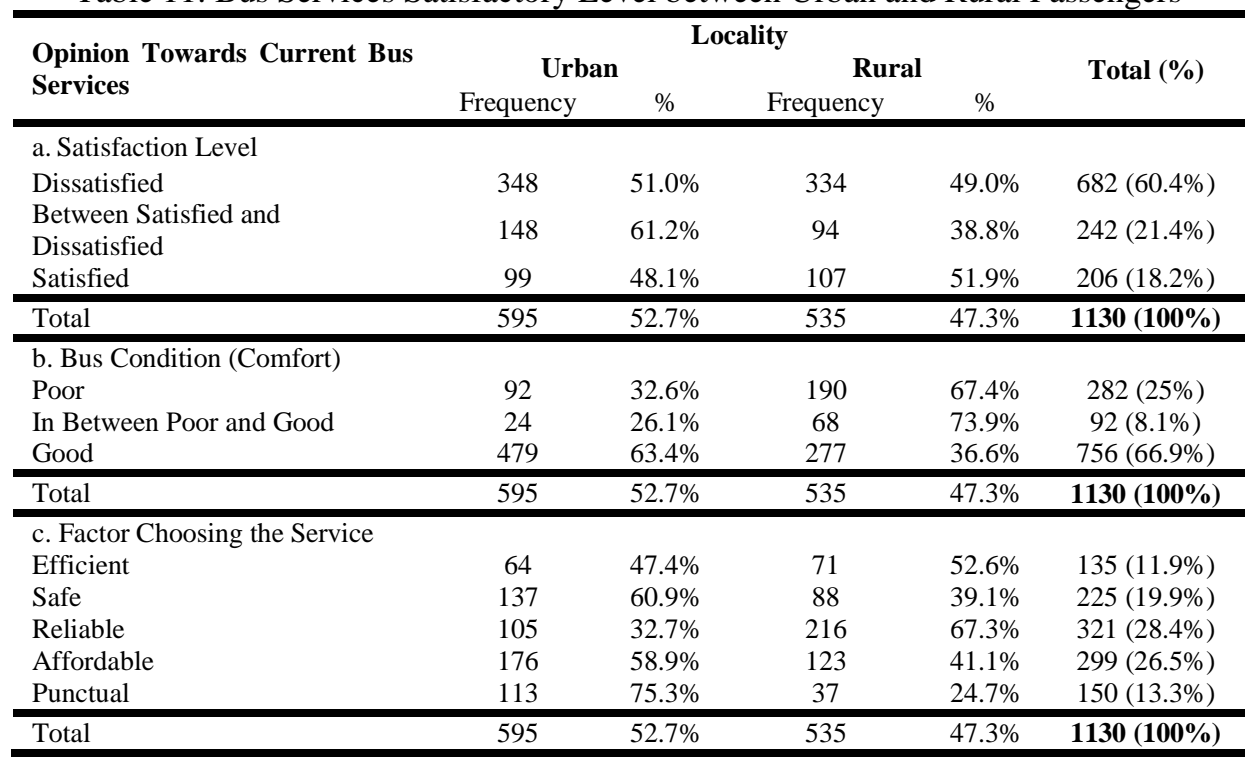

Table 12 shows further differences between urban and rural passengers by their disaggregated satisfaction levels.

Table 12: Passengers' Satisfaction Level

\begin{tabular}{|c|c|c|c|c|c|}
\hline \multirow[b]{2}{*}{ Satisfaction Level } & \multirow[b]{2}{*}{ Locality } & \multicolumn{3}{|c|}{ Quality Issue } & \multirow{2}{*}{$\begin{array}{c}\% \text { Within } \\
\text { Satisfaction } \\
\text { Level } \\
\text { According } \\
\text { Locality }\end{array}$} \\
\hline & & $\begin{array}{l}\text { Punctuality } \\
\text { \& Frequency }\end{array}$ & $\begin{array}{l}\text { Comfort \& } \\
\text { Clean }\end{array}$ & $\begin{array}{l}\text { Safety \& } \\
\text { Reliability }\end{array}$ & \\
\hline \multirow{2}{*}{ Dissatisfied } & Urban & $141(40.6 \%)$ & $50(14.4 \%)$ & $156(45 \%)$ & $347(30.7 \%)$ \\
\hline & Rural & $166(49.6 \%)$ & $75(22.4 \%)$ & $94(28.1 \%)$ & $335(29.6 \%)$ \\
\hline \multirow{2}{*}{$\begin{array}{l}\text { Between Satisfied } \\
\text { \& Dissatisfied }\end{array}$} & Urban & $52(45 \%)$ & $27(18.3 \%)$ & $70(36.7 \%)$ & $149(13.2 \%)$ \\
\hline & Rural & $47(34.9 \%)$ & $12(18.1 \%)$ & $34(47 \%)$ & $93(8.2 \%)$ \\
\hline \multirow{2}{*}{ Satisfied } & Urban & $32(50.5 \%)$ & $25(12.9 \%)$ & $42(36.6 \%)$ & $99(8.8 \%)$ \\
\hline & Rural & $52(48.6 \%)$ & $21(19.6 \%)$ & $34(31.8 \%)$ & $107(9.5 \%)$ \\
\hline \multicolumn{2}{|c|}{$\begin{array}{l}\text { \% within aspiration towards service } \\
\text { improvement }\end{array}$} & $490(43.4 \%)$ & $\begin{array}{c}210 \\
(18.6 \%)\end{array}$ & $430(38 \%)$ & $1130(100 \%)$ \\
\hline
\end{tabular}


Zakiah Ponrahono, Syahriah Bachok, Mariana Mohamed Osman, Mansor Ibrahim \& Muhammad Faris Abdullah \& Alias Abdullah Assessing The Urban And Rural Stage Bus Services Disparities In Peninsula Malaysia

One clear similarity that can be derived from the Table above is that urban and rural bus users put emphasis on punctuality and frequency (50.5\% and 48.6\% satisfied responses respectively). Safety and reliability are secondary to riders of both geographical locations (36.6\% and $31.8 \%$ satisfied responses respectively) when choosing to utilise bus services.

Two glaring disparities between urban passengers compared to their rural counterparts are that the former were more dissatisfied with safety and reliability (45\% compared to $28.1 \%$ ) and while the latter were more dissatisfied with punctuality and frequency (49.6\% compared with $40.6 \%$ agreeable responses respectively).

Table 12 provides further discussion on the differing treatments needed to improve the buses quality between the urban and rural services delivery. In rural areas, improvement aspired were more focused towards higher frequency and greater punctuality. Meanwhile, urban users were expecting more of safety assurance and reliability improvement with regards to the future bus services. Comfort and cleanliness were tertiary factors considered by passengers when evaluating the quality of the buses.

\section{CONCLUSION}

In summary, this study has identified Level of Service (LOS) as measurement tools for a quantitative assessment of bus services quality. The first objective of the study has been achieved by determining that the current services levels in Malaysia were LOS E which was lower than the threshold tolerated by many developed countries. Even more concerning is that there is a wide gap of services quality between urban and rural buses, namely the fixed hour service and passenger loads (weekend) i.e. LOS D and $\mathrm{F}$ respectively for urban areas compared to LOS C and $\mathrm{E}$ respectively for rural areas. The rural buses suffered from lower passenger's number and poorer fleet quality.

The second objective of the study was to ascertain the areas of improvements as aspired by the urban as oppose to rural passengers. It can be concluded that urbanites were more concerned about safety and reliability due to trips being made even during late hours while the rural passengers were emphasising on punctuality and frequency because services frequencies were lower and quality fleets have less capability to perform strictly adhering to published schedules.

These varied findings are consistent with several previous research in that there existed disparities between bus services in urban and rural areas (Abdullah, 2006; Ismail et al., 2012; Jayaraman et al., 2011; Ponnaluri, 2011; Suwardo et al., 2009; Yaakub \& Napiah, 2011a, 2011b). The findings not only further accentuated the facts there are gaps between quantitatively evaluated 
PLANNING MALAYSIA

Journal of the Malaysia Institute of Planners (2015)

performances in urban and rural buses (Aziz \& Amin, 2012; Bachok, 2007; Ismail et al., 2012; Jayaraman et al., 2011; Kamba et al., 2007), but also proved that the magnitude of such disparities are glaring especially in the improvements aspired by the passengers. Rural respondents were dissatisfied with buses frequency and punctuality but urbanites were more concerned with safety and reliability. This finding is coherent with the literature on regional disparities of buses services worldwide (Odeck \& Alkadi, 2004; Pucher \& Renne, 2013).

In conclusion, capital planning, infrastructure instalment and subsystem improvements are essential in the longer term planning of public transport system development. City region public transport operation, management and structure must be supported with a mature and more appropriate sustainable public transport provision guidelines and standards; through strict evaluation and proper use of indicators. Improving rural buses quality is of great importance because many services are facing dire issues, with more routes were susceptible to closure in the future should patronage continued to dwindle.

In short, the sustainability of public buses in Malaysia and the reduction of urban-rural gaps can be achieved first by implementing a comprehensive systems assessment through LOS identification and passengers' satisfaction surveys. 
Zakiah Ponrahono, Syahriah Bachok, Mariana Mohamed Osman, Mansor Ibrahim \& Muhammad Faris Abdullah \& Alias Abdullah Assessing The Urban And Rural Stage Bus Services Disparities In Peninsula Malaysia

\section{REFERENCES}

Abdullah, A. Z. (2006). Predicting the Impact of Demand- and Supply-Side Measures on Bus Ridership in Putrajaya, Malaysia. Journal of Public Transportation, 9(5), 57-70.

Ariffin, R. N. R., \& Zahari, R. K. (2013). Towards a Sustainable Urban Transport System in the Klang Valley, Malaysia: The Key Challenges. Procedia - Social and Behavioral Sciences, 85, 638-645. http://doi.org/10.1016/j.sbspro.2013.08.391

Aziz, A. A., \& Amin, N. F. M. (2012). Transforming the Land Public Transport System in Malaysia. JOURNEYS, (May), 30-37.

Bachok, S. (2007). What Do Passengers Need Out Of Public Transport Information Systems? What Do Passengers Information Systems. In CAITR-2007, 29th Conference of Australian Institutes of Transport Research. Transport System Centre (TSC). 1-13.

Bailey, A. J. (1986). Regulatory reform and rural bus service: Evidence from South Dakota. SocioEconomic Planning Sciences, 20(5), 291-298. http://doi.org/10.1016/0038-0121(86)90038-8

Bell, P., \& Cloke, P. (1991). Deregulation and Rural Bus Services - a Study in Rural Wales. Environment and Planning A, 23(1), 107-126. Retrieved from <Go to ISI>://A1991EZ09800007

Chen, X., Yu, L., Zhang, Y., \& Guo, J. (2009). Analyzing urban bus service reliability at the stop, route, and network levels. Transportation Research Part A: Policy and Practice, 43(8), 722-734. http://doi.org/10.1016/j.tra.2009.07.006

Cinquina, A. (2006). Sustainable public urban transport systems:The case of Curitiba. Lunds Universitet.

Clifton, K. J., \& Blohm, A. (2007). Vehicle Level of Service in Transit Station Areas : A Survey of Current Practice.

Cortés, C. E., Gibson, J., Gschwender, A., Munizaga, M., \& Zúñiga, M. (2011). Commercial bus speed diagnosis based on GPS-monitored data. Transportation Research Part C, 19(4), 695-707. http://doi.org/10.1016/j.trc.2010.12.008

Creswell, J. W. (2009). Research Design: Qualitative, Quantitative and Mixed Methods Approaches (3rd ed.). SAGE Publication Ltd.

Currie, G., \& Delbosc, A. (2014). Assessing Bus Rapid Transit system performance in Australasia. $\begin{array}{lllll}\text { Research in } & \text { Transportation }\end{array}$ http://doi.org/10.1016/j.retrec.2014.09.012

Dandapat, S., \& Maitra, B. (2015). An approach for identifying optimal service for rural bus routes. Case Studies on Transport Policy, 3(3), 287-294. http://doi.org/10.1016/j.cstp.2014.09.003

Department of Statistic Malaysia. (2014). Intercensal Mid-Year Population Estimates. Retrieved from http://www.statistics.gov.my/portal/download_Population/files/Anggaran_Penduduk_Pertenga han_Tahun_Antara_Banci2001_2009.pdf

Federal Department of Town and Country Planning Ministry of Housing and Local Government of Malaysia. (2010). Second National Physical Plan (NPP-2).

Hayashi, Y., Doi, K., Yagishita, M., \& Kuwata, M. (2004). Urban Transport Sustainability : Asian Trends , Problems and Policy Practices. EJTIR, 4(1), 27-45.

Hidding, M. C., \& Teunissen, a. T. J. (2002). Beyond fragmentation: New concepts for urban-rural development. Landscape and Urban Planning, 58(2-4), 297-308. http://doi.org/10.1016/S0169 2046(01)00228-6

Hook, W. (2006). Urban Transportation And The Millennium Development. Global Urban Development 2(1), 1-9.

Ismail, R., Hafezi, M. H., Nor, R. M., \& Ambak, K. (2012). Passengers Preference and Satisfaction of Public Transport in Malaysia. Australian Journal of Basic and Applied Sciences, 6(8), 410-416.

Jaramillo, C., Lizárraga, C., \& Grindlay, A. L. (2012). Spatial disparity in transport social needs and public transport provision in Santiago de Cali (Colombia). Journal of Transport Geography, 24, 340-357. http://doi.org/10.1016/j.jtrangeo.2012.04.014

Jayaraman, K., Choong, J., Suan, S., \& Lin, S. K. (2011). Robust models for the utilization of public bus transport services in Malaysia. African Journal of Business Management, 5(26), 10586-10600. http://doi.org/10.5897/AJBM11.510 
Kamaruddin, R., Osman, I., Anizaliana, C., \& Pei, C. (2012). Customer Expectations and its Relationship Towards Public Transport in Klang Valley. Journal of ASIAN Behavioural Studies, 2(5), 29-38

Kamba, A. N., Rahmat, R. A. O. K., \& Ismail, A. (2007). Why Do People Use Their Cars : A Case Study In Malaysia, 3(3), 117-122.

Land Public Transport Commission (SPAD). (2011). Greater Kuala Lumpur/Klang Valley Land Public Transport Master Plan: Travel Demand Management Plan. Klang Valley.

Land Public Transport Commission (SPAD). (2012). National Land Public Transport Masterplan.

Ministry of Transport Malaysia. (2014). Ministry of Transportation. Retrieved from http://www.mot.gov.my/my/Pages/Default.aspx

Ministry of Urban Development India. (n.d.). Service Level Benchmarks for Urban Transport at a Glance.

Napiah, M., Farid, amirah suriati A., \& Suwardo. (2010). Trip Productibity Evaluation of Bus Service: Medan Kidd Bus Station. In Proceeding of Malaysia Universities Transportation Research Forum and Conferences 2010 (MUTRFC2010) (Vol. 2010). Universiti Tenaga Nasional, Malaysia. 1-10.

Noor, H. M., Nasrudin, N., \& Foo, J. (2014). Determinants of Customer Satisfaction of Service Quality: City Bus Service in Kota Kinabalu, Malaysia. Procedia - Social and Behavioral Sciences, 153, 595-605. http://doi.org/10.1016/j.sbspro.2014.10.092

Nor, A. R. M., \& Nor, N. G. M. (2006). Empowering Public Transport for Urban Environmental Management. Malaysian Journal of Environmental Management, 7, 93-111.

Odeck, J. (2006). Congestion, ownership, region of operation, and scale: Their impact on bus operator performance in Norway. Socio-Economic Planning Sciences, 40(0038), 52-69. http://doi.org/10.1016/j.seps.2004.05.001

Odeck, J., \& Alkadi, A. (2004). The performance of subsidized urban and rural public bus operators: Empirical evidence from Norway. The Annals of Regional Science, 38(3), 413-431. http://doi.org/10.1007/s00168-003-0152-y

Olsson, J. (2012). Rural-urban spatial interaction in the global south: Long-distance mobility changes, desires and restrictions over two decades in rural philippines. Geografiska Annaler, Series B Human Geography, 94(3), 287-304. http://doi.org/10.1111/j.1468-0467.2012.00415.x

Orth, H., Dorbritz, R., \& Weidmann, U. (2011). Public Transport Capacity and Quality - Development of an LOS-Based Evaluation Scheme Public Transport Capacity and Quality - Development of an LOS-Based Evaluation Scheme. In 11th Swiss Transport Research Conference. Monte Verita Ascona. 1-16.

Patrick, R., \& Roseland, M. (2005). Developing sustainability indicators to improve community access to public transit in rural residential areas. Journal of Rural and Community Development, 1, 1 17.

Ponnaluri, R. V. (2011). Sustainable Bus Rapid Transit initiatives in India: The role of decisive leadership and strong institutions. Transport Policy, 18(1), 269-275. http://doi.org/10.1016/j.tranpol.2010.08.010

Pucher, J., \& Renne, J. L. (2013). Urban-Rural Differences in Mobility and Mode Choice: Evidence from the 2001 NHTS. Journal of Chemical Information and Modeling, 53, 1689-1699. http://doi.org/10.1017/CBO9781107415324.004

Rohani, M. M., Wijeyesekera, D. C., \& Karim, A. T. A. (2013). Bus operation, quality service and the role of bus provider and driver. Procedia Engineering, 53, 167-178 http://doi.org/10.1016/j.proeng.2013.02.022

Roslan, A. H. (2001). Income inequality, poverty and development policy in Malaysia. In Conference on Poverty and Sustainable development, (Vol. 4).

Royce A. Singleton, J., \& Straits, B. C. (2010). Approaches to Social Research (5th ed.). Oxford University Press.

Samir, D. K. (2001). LOS Evaluation of Improved Bus Services in Dhaka City. Journal of the Eastern Asia Society for Transportation Studies, 4(1), 235-250. 
Zakiah Ponrahono, Syahriah Bachok, Mariana Mohamed Osman, Mansor Ibrahim \& Muhammad Faris Abdullah \& Alias Abdullah Assessing The Urban And Rural Stage Bus Services Disparities In Peninsula Malaysia

Santoso, D. S., Yajima, M., Sakamoto, K., \& Kubota, H. (2012). Opportunities and strategies for increasing bus ridership in rural Japan: A case study of Hidaka City. Transport Policy, 24, 320 329. http://doi.org/10.1016/j.tranpol.2012.09.005

Sarantakos, S. (2005). Social Research (Third). Palgrave Macmillan.

Sham, R., Samsudin, N., \& Rahman, K. (2013). Managing Public Transport Service Operation in Reducing Travel Fear Factor. Procedia - Social and Behavioral Sciences, 101, 338-344. http://doi.org/10.1016/j.sbspro.2013.07.208

Sham, R., Soltani, S. H. K., Sham, M., \& Mohamed, S. (2012). Travel Safety Fear Factor among Vulnerable Group of Travelers: The Urban Scenario. Procedia - Social and Behavioral Sciences, 50 (July), 1033-1042. http://doi.org/10.1016/j.sbspro.2012.08.103

Siong, H. C. (2008). Urban Governance and Rapid Urbanization Issues in Malaysia. Jurnal Alam, 13(4), $1-24$.

State of Florida Department of Transport. (2013). 2013 Quality / Level of Service Handbook.

Suruhanjaya Pengangkutan Awam Darat (SPAD). (2014a). No Title. Retrieved from http://www.spad.gov.my

Suruhanjaya Pengangkutan Awam Darat (SPAD). (2014b). SHE Code of Practice (COP). Retrieved from http://www.spad.gov.my/function/she-guidelines

Suwardo, Napiah, M. B., \& Kamaruddin, I. B. (2008a). Puncuality and Expected Waiting Time of Stage Buses in Mixed Traffic. Jurnal Transpotasi, 8(Edisi Khusus No. 3), 213-226.

Suwardo, Napiah, M. B., \& Kamaruddin, I. B. (2009). On-Time Performance and Service Regularity of Stage Buses in Mixed Traffic. International Journal of Civil, Architectural Science and Engineering, 3(7), 1-8.

Suwardo, Napiah, M., \& Kamaruddin, I. B. (2008b). Review on Motorization and Use of Public Transport in Perak Malaysia: Realities and Challenges. In 2nd International Conference on Built Environment in Developing Countries (ICBEDC2008).

The City of San José. (2009). Traffic Impact Analysis Handbook: Volume 1 - Methodologies \& Requirements (Vol. I).

Thompson, E. C. (2004). Rural villages as socially urban spaces in Malaysia. Urban Studies, 41(12), 2357-2376. http://doi.org/10.1080/00420980412331297573

Transportation Research Board. (2003). Part 3 Quality Of Service Contents. In Transit Capacity and Quality of Service Manual 2nd Edition. 3-i to 3-94.

Transportation Research Board. (2013). Part 2 Bus Transit Capacity. In Transit Capacity and Quality of Service Manual Third Edition. 2-1 to 2-96. Retrieved from http://www.trb.org/main/blurbs/169437.aspx

Yaakub, N., \& Napiah, M. (2011a). Public Bus Passenger Demographic and Travel Characteristics. IEEE, $1-6$.

Yaakub, N., \& Napiah, M. (2011b). Public Transport: Punctuality Index for Bus Operation. World Academy of Science, Engineering and Technology, 60, 857-862.

Yamane, T. (1967). An Introductory Analysis. (Second Edition). New York: Harper and Row.

Zakaria, Z., Hussin, Z. H., Batau, M. F. A., \& Zakaria, Z. (2010). Service Quality of Malaysian Public Transports : ACase Study in Malaysia. Cross-Cultural Communication, 6(2), 84-92. 